
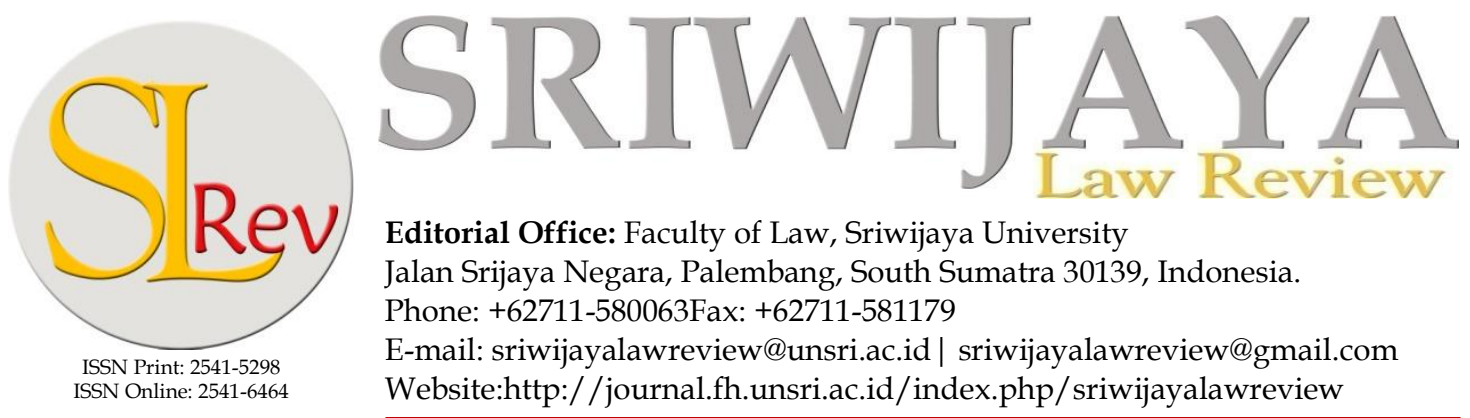

Editorial Office: Faculty of Law, Sriwijaya University

Jalan Srijaya Negara, Palembang, South Sumatra 30139, Indonesia.

Phone: +62711-580063Fax: +62711-581179

E-mail: sriwijayalawreview@unsri.ac.id| sriwijayalawreview@gmail.com

Website:http://journal.fh.unsri.ac.id/index.php/sriwijayalawreview

\title{
IMPROVING LEGAL ARGUMENT CRITICALLY IN THE LITI- GATION MECHANISM IN INDONESIA (AN EMPIRICAL STUDY OF ENVIRONMENTAL VERDICTS)
}

\author{
EdyLisdiyono
}

\begin{abstract}
Legal argument is a debate or argument in explaining the issues between two or more people performed in court.Legal argument is one way to perform lawfinding with the purpose to avoid legal vacuum when the judge makes a legal reasoning in a verdict. In making a legal argument,it is at least performed by legal reasoning, logic, facts. However,some judges, in making a decision,did not use the legal arguments by legal reasoning and facts so that it resulted in debates and arguments. It isinteresting to study on how to build legal argument in the litigation mechanism in Indonesia.Some verdicts in Indonesia have been the debate among the publicthrough social media, by both academic and non-academic communities, because they were not based on the legal facts revealed at the trials and not in favor of the public sense of justice. Some of the examples are the verdict in the case of the environmental lawsuits of LapindoBrantasMud in Sidoarjo, the case verdict in Palembang District Court on the lawsuit filed by the Ministry of Environment and Forestry on forest fires and land concessions of PT.BumiMekarHijau in 2014. From the decisions, it turned out that the judges, in making the legal arguments for theirdecisions, had deviated from the analogy and werenot based on the existing legal facts. In building legal arguments, itwould have to be conducted by collecting data (evidence) and clear fact so that its solutions do not deviate from the rules of law.
\end{abstract}

Keywords: environmental law; legal arguments;litigation mechanism.

\section{ARTICLE HISTORY:}

Received:

Dec 6, 2016; Reviewed: Dec 13, 2016

Accepted:

Dec 20, 2016; Published: Jan 30, 2017

Faculty of Law, 17 Agustus 1945 University, Semarang

E-mail:edylisdiyono@gmail.com

\section{INTRODUCTION}

After the 1998 reform, the society are increasingly open to view the legal issues decided by the Courts.People can see the decisions of the Courts downloaded via the internet in First Instance Court, Provincial Courts, or the Supreme Court and to study in the legal theories and logics by the academicians and the community of legal activists. In practice, the judges in Indonesia, in deciding cases, still adopt the positivistic school as taught by the philosopher Aguste- 
Comte; in every decision of the Court,judges still adheres to the valid rule of law although the decisions made deviate from the rule of law made by the law bearers. ${ }^{1}$ The doctrineof positive law that had been used by the law bearers (including police, prosecutor and judge) is sometimes unrecognized by many people particularly the rules of law (the laws and the regulations under the Laws) which are continuously changing. However,the huge number of laws and other regulations does not reflect that the society do not know the laws (Acts).The communities are considered to know, as it is called "the principle of legal fiction".Therefore, when people have a problem and dealing with the law, of course, people should be able to understand it so that the positive law remains to be studied continuously in the legal world.

When law is studied at the level of theory, in the progress, there has been the development at the level of practical studies by society openly, through social media. It can be seen in case trials in the courts both criminal and civil trials between judges, prosecutors, lawyers (in criminal cases) and the parties of Plaintiff and Defendant (in civil cases).Each party is always engaged in a debate that has always defended their statements by finding the logical justifications. In the academic world,the similar casesare also often encountered when academics were arguing about concepts, theories and regulations used by the law bearers.

By the community of law users, including legal experts and activists (observer),recently they constantly criticize, debate, and even blame the law bearers (the

Arief Sidharta, Refleksi tentang Hukum, Bandung, Citra Aditya Bakti, 1999, p142. executors) when the law is used to settle civil and criminal cases in litigation process.

Some of the verdicts of the courts have become the public spotlight both academics and non-academic when the judges decided cases.It was caused by the decisionsthat were not a fair trial (impartial) to one of the parties. As a matter of fact in the trials, the community had seen that the debate of the parties that convey the arguments of the law have been clear factually and juridicallyonthe right and wrong party.However, in reality, the decisions taken by the judges in court were different from the observations of the community in the world of law.It means that a judgment must have the legal objective, that is, to achieve the degrees of certainty, expediency and justice, as taught by Gustav Radbruch,a philosopher from Germany.

The fact is whether the three elements of such legal objective do not pose a problem or not because it hasbeen common that there is a clash between legal certainty and justice,the collision of legal certainty and expediency, and between justice and legal certainty. It can be seen from several decisions of legal cases, which were in juridical and factual decision of the court, in which the judges in making the legal reasoning in their verdicts had come out of the purposes of law so that it caused a debate in society. For example, it occurred in the decision of the lawsuits filed by WALHI against PT. MinaraLapindoBrantas in Sidoarjo, the Judicial Review by the Supreme Court against the corruptioncase of SudionoTiman, the verdict of Palembang District Court on the forest fires and land concessions of PT.BumiMekarHijau in 2014. 
This paper wanted to explore how to think logically in building critical legal arguments in the litigation mechanism in Indonesia since it was an empirical study of the verdicts and legal considerations of the debates occurred in among the academic community, legal activists, and observers.

\section{ANALYSIS AND DISCUSSION}

The casesreceivedby the Courtsallover Indonesia from year to year have always increased in line with the population growth, changes in globallife, and the problems faced by every human being. Therefore, if the courts should not refuse a case and have to be processed in a trial to be decided. In case of concrete events and should be resolved in court, judge will decide, in the event of lack of regulations or legislation, by finding the law. In the finding of law, there are several methods, i.e. interpretation method and argumentation method. In addition, there is also a newly developed method that may be used as the alternative to the finding of new law, namelythe hermeneutics of law.

Interpretation method is divided into; language interpretation, teleological or sociologicalinterpretation, systematic interpretation, historical interpretation, comparative interpretation, and futuristic interpretation. The method of law finding by means of interpretation of law isnot limited to legislation, but it concerns the whole law which is evolving in accordance with the unlimiteddynamics of human life.

In the discussion of this paper, itfocused only on one of the legal argumentsof the finding method in the litigation mechanism in Indonesia.

\section{Definition of Argument}

According to Vincent, in his Becoming a Critical Thinker: A Mater Student texts, argument is defined as: "The statement of a point of view and the evidence that supports it in a way intended to be persuasive to other people." Thus, argument is a statement supported by the evidence that can alter or affect the minds of others. Argument can also be defined as the process to strengthen a claim through critical thinking analysis based on the supportsof evidence and logical reasons. The evidence may contain facts or objective conditions that can be accepted as a truth ${ }^{2}$.

Of the two definitions, it is obvious that argument is a claim which is not merely delivered without basis. Argument must always be oriented to data, facts, or evidence objectively so that it can be accepted as a truth. Therefore, to argue, someone will conduct analysis and critical thinking. Furthermore, argument is also persuasive or may change as well as affect others' thoughts. When an argument is associated with legal arguments, in studying law, it is faced by resolving legal problems or conflicts, how to resolve a conflict, the laws or punishments are, and the person who is eligible. Therefore,Noll (in KusnuGoesniadhie) said ${ }^{3}$ that the science of law is the science of judiciary(rechtspraakwetenschap).It means that the study of law is viewed from the eyes of

\footnotetext{
Vincent Ryan Ruggiero(inKusnuGoesniadhie), 2009,Becoming a Critical Thinker, Boston: Houghton Mifflin Company, p. 59. http://www.pakandangan.go.id/index.php?content=mod_artikel\&id=17( retrieved: $16^{\text {th }}$ Mei 2015)

3 Velden, WG. Van der, De ontwikkeling van de WetgevingsWetenschap, Lelystad, Koninklijke Vermande, Noll, 1988,pp21-22.
} 
judges containing at least three characteristics, i.e.:

1. In relation with the individual events that result in the loss of others.

2. The application of a norm or rule (rule of law);

3. The resolution of a conflict in independent way without the influence of the interests of oneparty

The independence of judicial bodies/ judiciary as one of the bases for the creation of the judicial process offree trial (free and impartial) to find ultimate truth is important. The process of finding the truth can be influenced by subjectivity and objectivity. Truth and justice are essentially qualitative so that the neglect of the theoretical studies in Juridical Argument (legal reasoning) in legal education strengthens the tendency to think in positivistic (legalistic) in legal practices. The notion of legal reasoning is used in two meanings; in a broad and narrow sense. In broad terms, legal reasoning is associated with the psychological processes conducted by judges to be at a decision on the case handled by them. The study of legal reasoning, in a broader sense,is related to psychological and biographyaspects.

Legal reasoning, in the narrow sense, involves the argument underlying decisions. The study involves the study of the logic of a decision. In relation with these kinds of arguments, the relationship between reason (consideration, reason) and decision, as well as the accuracy of the reason or considerations which support the decision. ${ }^{4}$

Resolving legal issues juridically essentially means applying the rules of positive

4 Golding, Martin P, Legal Reasoning, New York,Alfreda A. KnoffInc,1984,p1. law regarding the problem (case). Applying the rules of positive law can only be performed contextually, interpret thelaws to find the legal norms contained therein, within the framework of the purpose of society from the establishment of the rule of law (teleological) related to underlying legal principles involving various methods ofinterpretation. (Grammatical , historical, systematical, and sociological).

The method of the making of law using argumentation theory is a way to examine how to analyze and formulate an argument in a clear and rational manner to develop the juridical criteria to be used as the rationality foundation of legal arguments. ${ }^{5}$ This argumentation theory is one of law finding by judges in handling and resolving the case at hand and the case has no regulationthat specifically set it in law. Therefore, according to the writer, legal argument is a scientific breakthrough made by judges at the time of making the decision due to legal vacuum with the aim of legal problem solving.

Aristotle had started thinking about how to solve legal problems in the event of legal vacuumstarted with the systematic studies of consistent logic from premise to conclusion. The notion underlying the determination of legal argumentation method is the number of new cases that arise in the community, while the laws havenot regulated them specifically. Then, judge can make legal arguments in order to address such cases in achieving a degree of legal justice.

To realize the legal justice in resolving legal cases that occur in the community,

Abdul Haris Semendawai, Argumentasi Hukum, Slidein PKPA held by PBHI-PERADI,tanggal 411 August 2008, p15. 
judge should use the method of juridical thinking with the following characteristics:

a. Argument (legal reasoning), which seeks to realize the consistency in the rules of law and legal decisions. The basis of thinking is the belief that law must be equal for everyone.

b. Dialectical reasoning occurs in legal reasoning, which weighs up contrary claims, either in the debate on the making of law or in the process of considering the views and facts presented by the parties in a judicial process.

Therefore, to analyze legal argument,it should use formal logic, while to analyze the rationality of proposition it uses syllogistical logic, propositional logic, and predicate logic. Logic is a line of thought that linksthe statement of a concept by providing reasoning through argumentation that plays the role in the process of argument rationality. A legal argument that is not supported by logic, facts, and evidence will have the impact on unlogical decisions so that it will make legal problem solving difficult for those seeking justice to understand them.

\section{Legal Argument}

In law finding, other than by interpretation, it is known the method of argument or commonly known aslegal construction. Different from interpretation method, this method is used when faced with the situation of legal vacuum (rechts vacuum). Meanwhile,in interpretation method,the events have been set in law, buttheregulation remains unclear. Based on the principle of ius curia novit (judge must not reject a case to be resolved with no legal argument or the law has not set it), argument way is one way to perform law finding in order not to have the legal vacuum when the judge makes decision. There are several ways to make legal arguments, i.e.: ${ }^{6}$

\section{Argumentum PerAnalogium(Analogi)}

Analogy is the way of law findingin which judges look for more common essence of a legal event or legal acts which are regulated by law or that there are no rules.

For example,it can be seen in article 1576 BW which stipulates that purchase does not terminate tenancy. Later in practice, the case is whether grant does not terminate a lease or vice versa? Because the law only regulates buying and selling and not on grants, the judge should perform law finding in order to make a decision in the case. By analogy method, firstly, judge seeks the essence of the act of buying and selling, which is the transfer of rights, and later finds the essence of grant action, which is also the transfer of rights. Thus, it was found that the transfer of rights is a genus (generalevent), while selling and grants are species respectively (specific event).Therefore,the analogy method uses induction logic; thinking fromspecific to general events. In conclusion, grants do not terminate a lease either. By analogy, similar, the same type, or comparable events stipulated in the law are treated equally.

\section{Argumentum a Contrario}

This method provides the opportunity for judges to perform legal finding with the consideration; if the law establishes certain

\footnotetext{
6 Sudikno Mertokusumo,Bab-Bab tentang Penemuan Hukum, Yogyakarta, Citra Aditya Bakti, 1993, p45.
} 
things for certain events, it means that the regulation is limited to certain events and, for the events out of it, it appliesin the reverse. Because there are times when an event is not specifically regulated by law, but the opposite of the event is set by law. Therefore, this method emphasizes on the interpretation waywhich is in the opposite understanding between the concrete events faced and the the events set forth in the law.

For example,theprovisionof iddah time which is the period of waiting time for a widow is stipulated in the Government Regulation No. 9 of 1975. In other hand, what about a widower? Does he have the iddah period? Act No. 1 of 1974 on Marriage does not explicitly regulate the iddah period for a divorced man.Therefore, to use the logic of a contrario that treats the reverse of the Government Regulation No. 9 of 1975, a widower does not have to wait for a certain time to marry again.

\section{Narrowing of Law}

Sometimes lawsare too general in scope or breadth, so it needs to be narrowed to be applied to a particular event. In narrowing laws, new exceptions or deviations are established fromgeneral regulations applied to specific events or a legal relationship with an explanation or construction by providing the characteristics.

For example, the narrowing of the law is in the definition of "action against the law" contained in article $1365 \mathrm{BW}$ with the broad scope of what law is. Consequently,the scope is narrowed into what we see in the jurisprudence of the decision of HR on January 31, 1919 to the case ofLindenbaumvs Cohen which the action against the law is narrowed into the action against the legislation and propriety.

\section{Some Examples Of The Verdicts Which Were Not Based On The Principles of Legal LogicThe Case of Lapindo Brantas}

On May 29, 2006, the mud burst from the ground in Siring village, Sidoarjo, East Java. This event was known as the Event of Lapindo Mud. Seven years have passed since the incident took place, and various efforts in the legal field have also been with unsatisfactory results. On December 27, 2007, WALHI lawsuit was rejected entirely by the verdict of the South Jakarta District Court. On October 27, 2008, WALHI lawsuit on appeal was also rejected by the verdict of the Jakarta Provincial Court strengthening the verdict of the South Jakarta District Court which stated that Lapindo hot mudflow was caused by natural disaster. WALHI did not file an appeal against the decision of the Jakarta Provincial Court, so it was considered that the verdict ofthe Jakarta Provincial Court had been in kracht. Following WALHI, YLBHI also filed a lawsuit to the Central Jakarta District Court on November 27, 2007, but the verdict of the Central Jakarta District Court said that the Government and PT. LapindoBrantas did not act against the law. YLBHI applied for appeal and cassationon 13 June 2008 and 3 April 2009, but the results of the decision also rejected the lawsuit of YLBHI and stated that the Government and PT. LapindoBrantaswere not guilty.

In the case of Lapindo mud, based on the Decision of the Supreme Court, stated that the case of Lapindo mudflow is a natural disaster. As a result, responsibility shifted to the state through the state budget funds 
each year. I think the verdict is not using the legal arguments and the facts of the law, because in the legal considerations described the judges as described Article 1365 of the Civil Code, namely about element losses not taking into account the popularity of legal justice, so that what is described by the community as the plaintiff in the description argument is accompanied by evidence not considered at all. Then the legal reasoning in the decision made by the judge majalis, does not make legal arguments which rely on other legal principles derived from other sources of law, namely Law No. 32, 2009, on changes to the Law No. 23 of 1997 on the Protection and Management of the Environment and not rooted in Act 26 of 2007 on Spatial Planning. Because in Protection Act and Environmental Management, known as the principle of "polluter pays principle" (the polluter pays principle) and the principle of "stict Liability" (accountability absolute) later in the arrangement of the room there is a criminal sanction of article 69 up to 73 . it should be taken as legal by the judges in making its decision, but the judges saw that Lapindo case with their loss was regarded as a natural disaster.

When the Lapindo case is regarded as a natural disaster, we can analogize whether flooding and environmental damage are really the cases of natural disaster or not. In my opinion, flooding and environmental damage are not merely natural disasters, but at least human intervention can be founddue to flooding and environmental damage. Therefore, it cannot be said that flooding and environmental damage are $100 \%$ natural disasters. Similar to the case of Lapindo, there was human intervention, namely PT. LapindoBrantas, in this case as the perpetrator of drilling which either directly or indi- rectly caused the mudflow which resulted in the case of Lapindo mud. This is analogized that the damages caused by the drilling ofLapindo should be considered by the judges in making their decision.

\section{The Verdict of Palembang District Court in the Case of Forest Fire}

Judges do have the freedom in deciding cases, but the freedom does not abandon the principles of law as the basic norms derived from positive law. When the judges of Palembang District Court decided the case of forest land and fires in the Sub-District ofTulungSelapan, OganKomeringIlir, South Sumatra, covering an area of 20,000 hectares, the decision rejected the civil lawsuit petition filed by the Ministry of Environment and Forestry in the amount of 7.9 Trillion against the concession company of PT. Bumi Mekar Hijau. The entire lawsuit of the plaintiffs can be proved, either in the form of loss or biodiversity damage, the defendant has been providing fire extinguishers in the plantation environment.

Finally, many people protested mainly academics and environmental activists at the verdict, but, in the consideration, the decision could be a discussion on its legal argument, and the decision ultimately must be respected.

When it is no longer the subject of conversation, I took one example to assess in terms of the legal arguments against the verdict.Then, the highlight is one of the considerations of the verdict.The judges mentioned that the forest fires were not damaging to the environment because it can be planted again, andthe fire that burned the lands came from the community land. However, the judges did not explain in detail the origin of the fire. 
In addition, the judges only saw the loss of one hand in the terms of the corporation. Meanwhile, the losses suffered by the community and the state were not included in the consideration of the decision. In other hand, people were directly impacted;they could not go to school because the schools were closed, flight disruptions due to smoke and the disaster mitigation budget should be spent by the State.

Finally the public made the petitions signed by 10,000 (ten thousand) people in "Change.org" against the decision of the District Court of Palembang on rhe forest fires. Furthermore, the Ministry of Environment and Forestry appealed, and the decision of the appellate court overturned the verdict the District Court of Palembang and in favor of the Ministry of Environment and Forests to impose on PT. Bumi Mekar Hijau to pay compensation to the State of Rp. 78 Billion.

Observing the verdict of the District Court of Palembang, the judges had made mistakes in making legal arguments because the judges used the method of argumentum a contrario. Occasionally, when an event is not specifically regulated by law, the opposite of the event is governed by law. Therefore, this method emphasizes the interpretation with the opposite understanding between the concrete event encountered and the event set forth in the legislation. Then, the analogy argumentation method should be used.

\section{Legal Argument in the Litigation Mechanism in Indonesia}

In every decision, the essence of the legal arguments in the legal consideration is the reason for the judge in making decisions determined by the legislation. The provisions of Article 50 paragraph (1) of Act No. 48 of 2009 mentionsthe Court's Decision should include the reasons and the basis of the decision, contain specific articles of the legislation or unwritten legal source which serve as the basis to the judge. The position of reason or argument is crucial. In a decision with no legal reasons in the consideration, the decision would be canceled by the court of appeal or cassation. The existence of legal argument in the legal consideration of a verdict is absolute. Consequently, the absence or lack of legal argument in a legal consideration may affect on the annulment of the decision. Legal consideration is the responsibility of judges for justice seekers.

The substance of the legal consideration of verdict lies in the consideration of its legal argument, while the quality of the legal argument depends on:

a. Simple reasoning,

b. Easily digestible, understandable

c. And understandably to anyone, including justice seekers.

Argument contains the reasons suggested for strengthening or rejecting a thought, idea, or establishment. ${ }^{7}$ Argument also has the meaning as a collection of statements that contain all of premises and conclusions. $^{8}$

Argument is a series of reasoning that shows the evidence that a particular statement is in a sequence from one or more other information. Besides, argument is giving

7 M. Dahlan, Y. Al Barry, L. Lya Sofyan Yakub,Kamus Induk Istilah Ilmiah, Surabaya, Targer Press, 2003,p58.

8 The Liang Gie, Kamus Logika, Third Edition, Yogyakarta, Liberty dan PBIUB, 1998. 
reason to reinforce or reject a legal opinion based on the logical law that follows the principles, rules, and laws that should be followed to reach the truth.

Legal argument is a type of reasoning that involves the intellectual process of law men in justifying doctrinal rationality, consistency, logic, and consistency to reach a conclusion in deciding a problem or issue (case) encountered. Rational legal argument consists of three layers: ${ }^{9}$

1. Logical layer. This layer is the internal structure of an argument and part of traditional logic. The issues arising are related to the premises used in drawing logical conclusions and steps in drawing conclusions, for example, deduction and analogy;

2. Dialectical layer. This layer compares the arguments both pros and cons. There are two parties in a dialogue or debate, which could ultimately not find an answer for they are both equally strong;

3. Procedural layer (structure, ways of dispute resolution). Procedure does not only organize a debate, but the debate even determines the procedure. A dialog rule should be based on the rules that have been defined by clear terms and conditions of rational procedures to dispute resolutions.

As stated by Bernard AriefSidharta ${ }^{10}$, legal argument consists of the elements of legal discourses, rhetoric, and logic that involve the application of the rules of formal

9 Abdullah,Pertimbangan Hukum Putusan Pengadilan, Surabaya, Program Pasca Sarjana Universitas Sunan Giri Publisher, 2008, p83.

10 Arief Sudharta, Note 1,p164. logic and the other method of ways of thinking exposure and preparation of arguments whhich are not always right. When an error occurs, it can be regarded as a failure of argument.

There are several causes of argument failure, such as:

1. Loading the premise (statement) of erroneous propositions. When a premise is false, the argument fails to establish the truth of conclusion;

2. Failure can occur because argument turns out to load the premises which are not associated with the conclusions that will be sought and

3. Ambiguity reasoning; the reasoning caused by people's carelessness and lack of attention to the related issues or wrong in the terms and propositions that have ambiguity. ${ }^{11}$

In presenting legal arguments, as a manifestation of responsibility, argument is prepared by applying legal reasoning, either deductive or inductive. At first, the judges use deductive reasoning by reloading the articles used as the basis of indictment, lawsuit, and petition. In the next stage, the judges combine deductive and inductive reasoning based on relevant legal theories.

Of the three decision examples, the judges should examine philosophically, that is, as the whole, fundamental, and speculative, and discuss them in depth ${ }^{12}$. This approach is intended to provide the foundation on the values of the judge's decision. In on-

11 E Sumarsono, Hermeneutik, Sebuah Metode Filsafat, Yogyakarta, Kanisius, 1999,pp9- 10.

12 Johnny Ibrahim,Teori dan Metodologi Penelitian Hukum Normatif, Surabaya, Bayumedia, 2005,p320. 
tology, essentially, a court decision should be associated with truth and justice before doing the review and assessment to legal facts, and it always begins by making the limits of the definitionson the elements of articles or propositions as the basis of the lawsuit of the litigants. ${ }^{13}$

\section{CONCLUSION}

Legal argument isa way to perform legal finding with the purpose to avoid a legal vacuum when the judges make a legal reasoning in a verdict. To establish legal argument in the litigation mechanism in Indonesia, at least, it is performed by legal reasoning, logic, and facts.

Reasoning can be conducted either deductive or inductive. When it contains the premise (statement) of wrong proposition, an argument fails to establish the truth of a conclusion. Failure can occur because the argument turns out to contain the premises which are not related to the conclusions to be searched.

As the verdict examples above, it turns out that the judges in their legal arguments to make decisions still used the statements which are not supported by the evidence and facts in the trial so that the verdict can mislead the law.

\section{REFERENCES}

Abdul-

lah.2008.PertimbanganHukumPutusanPeng adilan.Surabaya: Program PascaSarjanaUniversitasSunanGiri Publisher.

Gie,The Liang.1998.Kamus Logika, Third Edition. Yogyakarta: Liberty dan PBIUB.

http://www.pakandangan.go.id/index.php?c ontent=mod_artikel\&id=Velden, WG. Van der, 1988, De ontwikkeling van de wetgevingswetenschap, Lelystad. Koninklijke Vermande. Noll.

http://www.rappler.com/indonesia/118203petisi-putusan-kebakaran-hutanpengadilannegeri-palembang.

Ibrahim,Johnny. 2005. TeoridanMetodologiPenelitianHukumNormatif.Surabaya: Bayumedia.

Martin P. Golding. 1984.Legal Reasoning. New York:Alfreda A. Knoff Inc.

M. Dahlan Y. Al Barry, L. LyaSofyanYakub. 2003.KamusIndukIstilahIlmiah. Surabaya: Targer Press.

Mertokusumo,Sudikno. 1993.BabbabtentangPenemuanHukumYogyakarta: Citra AdityaBakti.

Semendawai, Abdul Haris.Argumentasi Hukum.Slidein PKPA held by PBHIPERADI, on 4-11 August 2008.

Sidharta,Arief. 1999.Refleksi tentang Hukum.Bandung: Citra Adiyta Bakti.

Sumarsono,E. 1999.Hermeneutik, SebuahMetodeFilsafat.Yogyakarta: Kanisius.

13 Abdullah. Note 9, p42. 